\title{
The Tolerance of Photosynthesis of Some Maize Cultivars (Zea mays L.) to Waterlogging at Different Stages of Growth
}

\author{
Sri Endang Agustina Rahayuningsih ${ }^{\#+}$, Didik Indradewa\#, Endang Sulistyaningsih ${ }^{\#}$, Azwar Maas* \\ ${ }^{\#}$ Departement of Agronomy, Faculty of Agriculture, Universitas Gadjah Mada, Yogyakarta 55281, Indonesia \\ E-mail: agustina_rahayuningsih@yahoo.com; didikindradewa54@yahoo.com; E-mail: endangsih@ugm.ac.id \\ *Departement of Soil Science, Faculty of Agriculture, Universitas Gadjah Mada, Yogyakarta 55281, Indonesia \\ E-mail:azwar.maas@gmail.com \\ ${ }^{+}$Department of Agronomy, Faculty of Agriculture, Universitas Palangka Raya, Palangka Raya 73112, Indonesia
}

\begin{abstract}
The tolerance of plants to waterlogging can be ascertained by identifying the characteristics of morphology, anatomy, and physiology of plants. As yet little is known about the photosynthetic characteristics of many cultivars of maize in Indonesia when waterlogged at various stages of growth. This research aimed to determine the photosynthesis tolerance of some maize cultivars to inundation that occurred at different stages of growth. The factorial completely randomized block design with two factors and three replications was used. The first factor consisted of nine maize cultivars, i.e. Bisi 2, Pioneer 21, Gumarang, Bisma, Sukmaraga, Srikandi Kuning 1, Bima 2, Bima 4, and Bima 5. The second was waterlogged conditions at different stages of growth i.e. the vegetative phase (leaved-four stage- - V4 stage), the early phase of reproduction (silk phase - R1 stage), and the middle phase of reproduction (milk stage - R3 stage), and no water logging as the control. During the period of waterlogging, the water level of $5 \mathrm{~cm}$ was maintained for 10 days. The results showed that no interaction effect between maize cultivars and waterlogging conditions to almost all photosynthesis variable except stomatal aperture. Ten days of waterlogging at different stages of growth affected photosynthesis by decreasing the chlorophyll content (a, b and total), photosynthetic rate, and the stomatal aperture width. The R1 stage was the stage of growth sensitive to photosynthesis when waterlogged. Bisma cultivar is the maize cultivar that is not tolerant to waterlogging stress at the V4 stage and Gumarang is not tolerant at the R3 stage. It showed a low rate of photosynthesis. At the R1 stage, Bima 5 and Bima 2 cultivars are the maize cultivars that are tolerant to waterlogging stress, while at the R3 stage all cultivars are tolerant except Gumarang. Therefore, Bima 5 and Bima 2 cultivars can be recommended to be planted in the swampy areas.
\end{abstract}

Keywords — tolerance; photosynthesis; cultivar; maize; waterlogging

\section{INTRODUCTION}

Waterlogging is a major problem in many agricultural areas in the world. On dry land, waterlogging is caused by the leakage in irrigation dikes or excessive irrigation [1], [2]. Waterlogging can also be caused by rising sea levels due to the climate change and global warming [3], while according to [4], it can be caused by the geographical characteristics such as the Mekong River Delta in Vietnam. In swampy areas, such as in Palangka Raya, Central Kalimantan, waterlogging usually occurs as a result of the overflowing tide from Kahayan River directly or indirectly, or because an area is very low or a basin with bad drainage.

Waterlogging impacts are complex and vary depending on the genotype, and growth rate of plants at the time of waterlogging, the extent and duration of waterlogging [5], [6], and [7]. One of the effects of waterlogging is oxygen deficiency [8] that reduces the photosynthetic rate [1] and assimilation of $\mathrm{CO}_{2}$ [9]. Waterlogging inhibits roots respiration resulting in the lack of energy to absorb water and nutrients from the soil, causing a stomatal closure. This condition will reduce the content of $\mathrm{CO}_{2}$ entering through the leaf and reduce the rate of photosynthesis.

Photosynthesis process is the important factor to improve growth, development, and yield. Generally, photosynthesis is influenced by some factors such as plant genetics [10], plant age [11], leaf age [12], leaf chlorophyll [13], density and anatomy of stomata [14], and environment [15]. In addition to the character of photosynthesis, the high decrease in the growth of waterlogged plants is determined by the plant growth phase and the duration of inundation. Ten days of the duration of inundation resulted in poor growth [16]. In the corn plants that were flooded at the phase of V2 (two-leaved stage - V2 stage) and V3 (three-leaved stage - V3 stage), the 
survival rate of their population was reduced to 76-93\% [17]. Plants that are susceptible to physiological disorders due to waterlogging could affect both phases of vegetative and generative growth[18]. Some genotypes of maize are capable of adapting to the waterlogged condition through physiological adaptation and genetic mechanisms [19], [20].

The tolerance of plants to waterlogging according to [1] can be achieved through avoidance or tolerance. The tolerance strategy to a waterlogged condition is the ability to sustain high levels of growth, biomass accumulation and yield [6]. According to [21], waterlogging tolerance is defined as the survival and maintenance of plant growth under a relatively extensive waterlogged condition in comparison to a well-drained condition. A tolerant plant would be able to adapt by developing some adjustments that ultimately make the plants capable of performing photosynthesis, although the photosynthesis performance was not as well as when the plant does not experience waterlogging [22].

The ability of plants to grow and thrive in the waterlogging condition highly depends on the interaction between varieties of plant. Superior maize varieties developed in Indonesia were drought-resistant varieties, but no information about the tolerance of maize varieties to inundation. Therefore, it is needed to study maize tolerance to waterlogging in different growth stage by identifying-the characters of plant physiology

\section{MATERIAL AND METHODS}

The research was conducted from June to December 2013 at the Experimental Farm of Faculty of Agriculture, Universitas Gadjah Mada.

The research was polybags experiment arranged in a completely randomized block design with two factors and three replications. The first factor was composed of 9 maize cultivars, namely Bisi 2, Pioneer 21, Gumarang, Bisma, Sukmaraga, Srikandi Kuning 1, Bima 2, Bima 4, and Bima 5. The second factor was waterlogged conditions in the different growth stage i.e. in the vegetative phase (fourleaved stage - V4 stage); in the early phase of reproduction (silk stage - R1 stage); and in the middle phase of reproduction (milk stage - R3 stage), and a control (an untreated/ not waterlogged).

Twenty-four cm diameter polybag was filled with $15 \mathrm{~kg}$ of air-dry soil taken from former paddy fields. Maize grown in soil media in the polibag holes are given (a way for the incoming water), while the polybag was submerged in a bucket under a larger and high surface puddles outside the pot. The soil in the polybag was not given water, but the water was obtained or derived from infiltration of water from the catchment that lies outside the pot (the water in the bucket). Fertilization used cow manure and fresh straw mixed with the soil amounting to $5 \mathrm{tha}^{-1}$ and $10 \mathrm{tha}^{-1}, 0.35 \mathrm{t}$ urea for ha ${ }^{-1}, 0.15 \mathrm{tha}^{-1} \mathrm{SP} 36,0.15 \mathrm{t} \mathrm{ha}^{-1} \mathrm{KCl} \mathrm{tha}{ }^{-1}$. In each polybag, 3-4 seeds were planted, and then one seedling per polybag was allowed to 7 days after germination.

Waterlogging was prepared by pouring the water into the bucket so that the water infiltration into the polybag by means of capillaries. Each plant was submerged in $5 \mathrm{~cm}$ of water for 10 days of waterlogging (inundation). After the treatment was complete, each polybag was removed from the bucket to let the water out of the pot holes naturally. In the controlled treatment, soil moisture was maintained at field capacity during growth of maize.

Observations of photosynthesis variables consisted of the rate of photosynthesis, chlorophyll content ( $\mathrm{a}, \mathrm{b}$ and total), and stomata (stomatal density and stomatal aperture width). Observations were made on the 10th day after waterlogging treatment on each waterlogging treatment. The chlorophyll content ( $a, b$ and total) were observed using leaf samples calculated by Shimadzu 1201 spectrophotometer at wavelengths of 645 and $663 \mathrm{~nm}$. Calculation of chlorophyll content was determined by applying the formula [23]. The formula is as follows:

$$
\begin{gathered}
\text { Chl a }(\mathrm{g} \mathrm{l}-1)=0.0127 \mathrm{~A} 663-0.00269 \mathrm{~A} 645 \\
\text { Chl b }(\mathrm{g} \mathrm{l}-1)=0.0029 \mathrm{~A} 663-0.00468 \mathrm{~A} 645 \\
\text { Total Chl }(\mathrm{g} \mathrm{l}-1)=0.0202 \mathrm{~A} 663+0.00802 \mathrm{~A} 645
\end{gathered}
$$

Observation of density and stomatal aperture width based imprints of the leaf surface by coating the leaf surface with nail varnish and using a microscope at a magnification of 10 $\mathrm{x}$ 40. The rate of photosynthesis was observed using a Portable Photosynthesis System Li-6400.

Data were analyzed by using the analysis of variance at the level of 5 percent and the Duncan Multiple Range Test at the same level. To see the relationships between the variables of photosynthesis were analyzed using Pearson correlation test at the level of 0.05. All analysis data were calculated in SAS program Portable 9.1.3.

\section{RESULTS AND DISCUSSION}

The results showed that there was no interaction effect between cultivars with waterlogging on photosynthesis and all the variable components supporting all stages of growth except at the R1 stage. Table 1 shows that at the four-leaved stage plants (V4), there was no difference in the supporting component of photosynthesis, but there were differences in the rate of photosynthesis between cultivars tested. Bisma had the lowest rate of photosynthesis. Within the flowering stage (R1), there were differences in all the variables photosynthesis. Bima 5 and Bima 2 had the highest photosynthesis rate. While in the seed filling stage (R3) the result was relatively uniform with cultivar Gumarang indicating significant lower photosynthetic rate, than those of other cultivars.

Table 1 shows that the V4 stage led to a decrease in photosynthesis and in almost all of its components. In V4 stage, plants with a waterlogged treatment in phases R1 and R3 actually no puddle, so that the rate of photosynthesis and supporting components of photosynthesis did not differ from the plants that were not stagnant.

In phase $\mathrm{R} 1$, inundation also led to a decrease in photosynthesis and in almost all of its components. The plants that were flooded in the vegetative phase and not flooded again in the flowering phase (R1) showed increasing chlorophyll levels that exceeded those of the plants that were not stagnant, but their stomata did not recover. Thus, their photosynthetic rates did not show a significant difference from those of the plants that were not flooded. At the time of the flowering phase, the plants with the R3 treatment had not been waterlogged. They had higher chlorophyll than those 
that were not waterlogged, but with stomatal density and smaller openings resulted in the rate of photosynthesis that was not different from that of plants that were not waterlogged.

In phase R3, waterlogging decreased chlorophyll content and stomata, but did not significantly reduce the rate of photosynthesis. The chlorophyll contents and stomatal openings of the plants that were once inundated in the vegetative growth and not flooded again at the time of flowering and seed filling could recover but the density of stomata could not. Nevertheless, these plants had the rate of photosynthesis that was not different from the plants that were not flooded. The chlorophyll content and stomata of the plants that were once inundated at the time of flowering and seed filling could not recover. Nevertheless, these plants had photosynthesis rates that were not different from those of the plants that were never flooded.

Table 1 shows that photosynthesis in the vegetative phase-correlated with the chlorophyll content, both chlorophyll a, chlorophyll $\mathrm{b}$ and total chlorophyll, but had no correlation with the stomata, either the density or stomatal openings. In the flowering phase, the photosynthesis only correlated with the content of chlorophyll $b$ and total chlorophyll, while in the seeding phase, the photosynthesis did not correlate with the chlorophyll content and stomata.

It has been reported that waterlogging affects the process of photosynthesis in plants [6], [24]. This research shows that waterlogging decreased the rate of photosynthesis, chlorophyll content and stomatal closure of maize plant. This was consistent with [25] that the reduction in photosynthesis in flooded plants was due to stomatal closure and decreasing photosynthetic capacity. Decreasing photosynthesis in inundated plants was also due to reduced leaf chlorophyll [26], [24]. Chlorophyll plays a major role in the absorption of light during photosynthesis. A decrease in chlorophyll content can also decrease the efficiency of plants in converting light energy into chemical energy, thus reducing the rate of photosynthesis.

Considering the stage of plant growth, the effects of waterlogging at the vegetative stage (V4) when they were not flooded could be recovered, but the effects of inundation in the flowering stage (R1) after the plants were not flooded again could not. Even plants that were flooded at the flowering stage turned out to have awfully decreased photosynthetic rates and when not flooded again, their chlorophyll content and the stomata could not be recovered although their photosynthetic rates were not different from those of the plants that were never stagnant. This indicates that the flowering stage was a sensitive stage for the photosynthesis of maize plants in this study. This is in accordance with [27] that the R1 stage is the most sensitive to environmental stress within the lifecycle of maize plants. It is added by [28] that the R1 stage, as the initial stage of reproduction and the final stage of vegetation, was the critical growth stage. Stress during this stage could reduce the rate of photosynthesis, such as in cotton plants [29] flooded at the flowering stage, which was the critical growth stages that would affect later development.

The declining rate of photosynthesis during the inundation period was different between each cultivar. In Bisma, during the inundation period at the stage V4, it showed a low rate of photosynthesis. At the stage R1, Bima 5 and Bima 2 showed a high rate of photosynthesis, while at the stage $\mathrm{R} 3$, all cultivars had the rate of photosynthesis that was not different. This indicated that Bisma cultivar was not tolerant to inundation at the V4 stage and Gumarang was not tolerant to inundation at the R3 stage, while Bima 5 and Bima 2 were tolerant to waterlogging at R1 and R3 stages. When not inundated, the content of chlorophyll ( $\mathrm{a}, \mathrm{b}$, and total) in the plants that were once inundated was restored indicated by increasing chlorophyll a, chlorophyll b, and total, and reopened stomata. This is shown on waterlogged plants in the V4 stage that at R1 and R3 stages the width of stomatal aperture increased, equal to that of the control (Table 1). Likewise, the plants that were waterlogged at R1 stage showed increasing stomatal aperture at the R3 stage.

Results of this research showed that at the V4 stage, the chlorophyll content (a, b, and total) decreased by 78\%, 75\%, and $77 \%$ compared with those of the controls. At the time of waterlogging applied to R1 stage, the chlorophyll content (a, $\mathrm{b}$ and total) decreased by $14 \%, 6 \%$, and $10 \%$ compared with those of the control; whereas the plants that were inundated at V4 stage and not inundated again at R1 stage showed increasing chlorophyll content, which exceeded that of the plants that were not inundated. Waterlogging applied to R3 stage indicated decreasing chlorophyll content ( $\mathrm{a}, \mathrm{b}$ and total) by $20 \%, 14 \%$, and $17 \%$ compared with those of the control. There was no significant difference in the chlorophyll content ( $\mathrm{a}, \mathrm{b}$ and total) among the cultivars when plants were inundated at the V4 stage. Yet, there were significant differences in the chlorophyll content ( $\mathrm{a}, \mathrm{b}$ and total) among cultivars when plants were inundated at R1 and R3 stages (Table 1). This is consistent with the research on waterlogged maize in India [30]. The total chlorophyll content of waterlogged maize at the age of 36 and 46 days after germination was also reported to decrease by $20.19 \%$ and $14.68 \%$, respectively [31].

Inundation effect on stomata in this research showed that inundation causes stomatal closure but does not affect the density of stomata. It is similar in sugarcane that stress does not affect the density of stomata [32]. Stomatal density is determined by the age of the plant and the increase of leaf area [33]. Although inundation affects stomata, photosynthesis was not correlated to stomata at all phases of the plant. This shows that the photosynthetic rate of maize in this research was not affected by the stomata, but, there might be roles other than stomata. There was a possibility of damage of the photosynthetic apparatus, resulting in chlorophyll degradation as shown in Table 1 that during waterlogging treatment, chlorophyll content (a, b and total) was lower than that of the control. As reported by [34], the stomatal closure was not a major limitation of decreasing photosynthetic rate. Instead, the influence of the non-stomata on the process of photosynthesis played a bigger role in decreasing the photosynthetic rate. This is in accordance with [35] that the stomatal closure does not restrict the entry of $\mathrm{CO}_{2}$ into the leaves. 
TABLE I

The Photosynthetic Rate and Variables of Photosynthesis of Some Maize Cultivars in Waterlogging at Different Growth Stages

\begin{tabular}{|c|c|c|c|c|c|c|}
\hline Treatment & $\begin{array}{c}\text { Chlorophyll } \\
\text { a }\left(\mathrm{mg} \mathrm{g}^{-1}\right)\end{array}$ & $\begin{array}{l}\text { Chlorophyl } \\
\text { l b }\left(\mathrm{mg} \mathrm{g}^{-1}\right)\end{array}$ & $\begin{array}{l}\text { Chlorophyll } \\
\text { total }\left(\mathrm{mg} \mathrm{g}^{-1}\right)\end{array}$ & $\begin{array}{c}\text { The density } \\
\text { of stomata } \\
\left(\mu \mathrm{m}^{-2}\right)\end{array}$ & $\begin{array}{c}\text { Stomatal } \\
\text { aperture width } \\
(\mu \mathrm{m})\end{array}$ & $\begin{array}{l}\text { Photosynthetic } \\
\text { rate }\left(\mu \mathrm{mol} \mathrm{CO}_{2}\right. \\
\left.\mathrm{m}^{-2} \mathrm{~s}^{-1}\right)\end{array}$ \\
\hline \multicolumn{7}{|l|}{ V4 stage Cultivar (V) } \\
\hline Bisi 2 & 0.123 & 0.499 & 0.502 & 58.1 & 2.850 & $107.08 \mathrm{abc}$ \\
\hline Pioneer 21 & 0.126 & 0.513 & 0.515 & 58.3 & 3.008 & $111.42 \mathrm{a}$ \\
\hline Gumarang & 0.105 & 0.472 & 0.453 & 57.1 & 2.983 & $106.75 \mathrm{abc}$ \\
\hline Bisma & 0.130 & 0.495 & 0.511 & 58.2 & 2.783 & $103.01 \mathrm{c}$ \\
\hline Sukmaraga & 0.145 & 0.521 & 0.552 & 51.4 & 2.458 & $109.33 \mathrm{ab}$ \\
\hline Srikandi Kuning & 0.088 & 0.424 & 0.397 & 55.9 & 2.717 & $106.58 \mathrm{abc}$ \\
\hline Bima 2 & 0.130 & 0.489 & 0.507 & 57.1 & 2.650 & $106.83 \mathrm{abc}$ \\
\hline Bima 4 & 0.099 & 0.472 & 0.442 & 54.2 & 2.525 & $107.23 \mathrm{abc}$ \\
\hline Bima5 & 0.130 & 0.482 & 0.504 & 56.9 & 2.567 & $104.43 \mathrm{bc}$ \\
\hline F test & $\mathrm{ns}$ & $\mathrm{ns}$ & $\mathrm{ns}$ & ns & ns & $*$ \\
\hline \multicolumn{7}{|l|}{ Waterlogging $(\mathrm{G})$} \\
\hline Control & $0.153 \mathrm{a}$ & $0.592 \mathrm{a}$ & $0.607 \mathrm{a}$ & $56.8 \mathrm{ab}$ & $2.783 \mathrm{a}$ & $107.63 \mathrm{a}$ \\
\hline At the V4 stage & $0.033 \mathrm{~b}$ & $0.148 \mathrm{~b}$ & $0.142 \mathrm{~b}$ & $58.5 \mathrm{a}$ & $1.942 \mathrm{~b}$ & $102.70 \mathrm{~b}$ \\
\hline At the R1 stage & $0.142 \mathrm{a}$ & $0.588 \mathrm{a}$ & $0.586 \mathrm{a}$ & $55.4 \mathrm{ab}$ & $2.875 \mathrm{a}$ & $108.83 \mathrm{a}$ \\
\hline At the R3 stage & $0.150 \mathrm{a}$ & $0.612 \mathrm{a}$ & $0.614 \mathrm{a}$ & $53.5 \mathrm{~b}$ & $2.858 \mathrm{a}$ & $108.69 \mathrm{a}$ \\
\hline F test & $* *$ & ** & $* *$ & $*$ & $* *$ & $* *$ \\
\hline \multicolumn{7}{|l|}{$\mathrm{V} \times \mathrm{G}$} \\
\hline $\mathrm{F}$ test & ns & $\mathrm{ns}$ & ns & ns & ns & ns \\
\hline \multicolumn{7}{|c|}{ R1 stage Cultivar (V) } \\
\hline Bisi 2 & $0.289 \mathrm{a}-\mathrm{d}$ & $0.721 \mathrm{~cd}$ & $0.924 \mathrm{bc}$ & $104.5 \mathrm{bc}$ & $3.050 \mathrm{~d}$ & $355.67 \mathrm{~b}$ \\
\hline Pioneer 21 & $0.320 \mathrm{a}$ & $0.807 \mathrm{ab}$ & $1.029 \mathrm{a}$ & $106.8 \mathrm{abc}$ & $3.208 \mathrm{~cd}$ & $333.50 \mathrm{~b}$ \\
\hline Gumarang & $0.278 \mathrm{~b}-\mathrm{d}$ & $0.759 \mathrm{bcd}$ & $0.927 \mathrm{ab}$ & $98.5 \mathrm{~cd}$ & $4.150 \mathrm{a}$ & $336.17 \mathrm{~b}$ \\
\hline Bisma & $0.263 \mathrm{~cd}$ & $0.726 \mathrm{~cd}$ & $0.880 \mathrm{bc}$ & $104.2 \mathrm{bc}$ & $3.567 \mathrm{a}-\mathrm{d}$ & $369.67 \mathrm{ab}$ \\
\hline Sukmaraga & $0.250 \mathrm{de}$ & $0.694 \mathrm{~d}$ & $0.838 \mathrm{ac}$ & $93.4 \mathrm{~d}$ & $3.792 \mathrm{a}-\mathrm{c}$ & $329.50 \mathrm{~b}$ \\
\hline Srikandi Kuning & $0.276 \mathrm{bd}$ & 0.782 abc & $0.935 \mathrm{ab}$ & $112.8 \mathrm{ab}$ & $3.692 \mathrm{a}-\mathrm{c}$ & $337.58 \mathrm{~b}$ \\
\hline Bima 2 & $0.302 \mathrm{a}-\mathrm{c}$ & $0.818 \mathrm{ab}$ & $1.002 \mathrm{a}$ & $112.1 \mathrm{ab}$ & $3.433 \mathrm{~b}-\mathrm{d}$ & $394.50 \mathrm{a}$ \\
\hline Bima 4 & $0.223 \mathrm{e}$ & $0.688 \mathrm{~d}$ & $0.786 \mathrm{bc}$ & $108.2 \mathrm{ab}$ & $4.050 \mathrm{ab}$ & $356.83 \mathrm{~b}$ \\
\hline Bima5 & $0.305 \mathrm{ab}$ & $0.840 \mathrm{a}$ & $1.020 \mathrm{a}$ & $114.7 \mathrm{a}$ & $3.592 \mathrm{a}-\mathrm{d}$ & $401.17 \mathrm{a}$ \\
\hline F test & $* *$ & $* *$ & $* *$ & $* *$ & $* *$ & $* *$ \\
\hline \multicolumn{7}{|l|}{ Waterlogging $(\mathrm{G})$} \\
\hline Control & $0.286 \mathrm{~b}$ & $0.744 \mathrm{~b}$ & $0.932 \mathrm{~b}$ & $110.2 \mathrm{a}$ & $4.400 \mathrm{a}$ & $378.41 \mathrm{a}$ \\
\hline At the V4 stage & $0.321 \mathrm{a}$ & $0.834 \mathrm{a}$ & $1.046 \mathrm{a}$ & $108.1 \mathrm{~b}$ & $3.567 \mathrm{~b}$ & $354.52 \mathrm{a}$ \\
\hline At the R1 stage & $0.219 \mathrm{c}$ & $0.683 \mathrm{~b}$ & $0.777 \mathrm{c}$ & $116.1 \mathrm{a}$ & $2.692 \mathrm{c}$ & $326.41 \mathrm{~b}$ \\
\hline At the R3 stage & $0.287 \mathrm{~b}$ & $0.777 \mathrm{~b}$ & $0.952 \mathrm{~b}$ & $113.4 \mathrm{a}$ & $4.108 \mathrm{ab}$ & $369.37 \mathrm{a}$ \\
\hline F test & $* *$ & $* *$ & $* *$ & $* *$ & $* *$ & $* *$ \\
\hline \multicolumn{7}{|l|}{$\mathrm{V} \times \mathrm{G}$} \\
\hline $\mathrm{F}$ test & ns & $\mathrm{ns}$ & ns & $*$ & $*$ & $\mathrm{~ns}$ \\
\hline \multicolumn{7}{|c|}{ R3 stage Cultivar $(\mathrm{V})$} \\
\hline Bisi 2 & $0.223 \mathrm{bc}$ & $0.681 \mathrm{ab}$ & $0.783 \mathrm{bc}$ & 109.7 & 3.358 & $434.33 \mathrm{a}$ \\
\hline Pioneer 21 & $0.304 \mathrm{a}$ & $0.749 \mathrm{a}$ & $0.967 \mathrm{a}$ & 114.0 & 3.133 & $445.00 \mathrm{a}$ \\
\hline Gumarang & $0.248 \mathrm{ab}$ & $0.730 \mathrm{a}$ & $0.856 \mathrm{ab}$ & 104.5 & 3.792 & $355.92 \mathrm{~b}$ \\
\hline Bisma & $0.175 \mathrm{c}$ & $0.572 \mathrm{~b}$ & $0.636 \mathrm{c}$ & 106.7 & 3.200 & $421.83 \mathrm{a}$ \\
\hline Sukmaraga & $0.277 \mathrm{ab}$ & $0.738 \mathrm{a}$ & $0.912 \mathrm{ab}$ & 101.9 & 3.700 & $423.08 \mathrm{a}$ \\
\hline Srikandi Kuning & $0.264 \mathrm{ab}$ & $0.753 \mathrm{a}$ & $0.897 \mathrm{ab}$ & 107.1 & 3.667 & $440.58 \mathrm{a}$ \\
\hline Bima 2 & $0.253 \mathrm{ab}$ & $0.740 \mathrm{a}$ & $0.870 \mathrm{ab}$ & 107.4 & 3.892 & $401.92 \mathrm{a}$ \\
\hline Bima 4 & $0.275 \mathrm{ab}$ & $0.801 \mathrm{a}$ & $0.943 \mathrm{ab}$ & 104.7 & 3.667 & $413.83 \mathrm{a}$ \\
\hline Bima5 & $0.249 \mathrm{ab}$ & $0.708 \mathrm{a}$ & $0.846 \mathrm{ab}$ & 106.5 & 3.450 & $441.50 \mathrm{a}$ \\
\hline F test & $* *$ & $*$ & $* *$ & ns & ns & $* *$ \\
\hline \multicolumn{7}{|l|}{ Waterlogging $(\mathrm{G})$} \\
\hline Control & $0.295 \mathrm{a}$ & $0.777 \mathrm{a}$ & $0.966 \mathrm{a}$ & $111.6 \mathrm{a}$ & $4.117 \mathrm{a}$ & 433.52 \\
\hline At the V4 stage & $0.308 \mathrm{a}$ & $0.831 \mathrm{a}$ & $1.019 \mathrm{a}$ & $101.7 \mathrm{~b}$ & $4.375 \mathrm{a}$ & 422.70 \\
\hline At the R1 stage & $0.169 \mathrm{c}$ & $0.598 \mathrm{~b}$ & $0.639 \mathrm{c}$ & $107.6 \mathrm{a}$ & $3.492 \mathrm{~b}$ & 420.19 \\
\hline At the R3 stage & $0.236 \mathrm{~b}$ & $0.672 \mathrm{~b}$ & $0.802 \mathrm{~b}$ & $104.8 \mathrm{~b}$ & $2.692 \mathrm{c}$ & 402.70 \\
\hline $\mathrm{F}$ test & $* *$ & $* *$ & $* *$ & $* *$ & $* *$ & ns \\
\hline \multicolumn{7}{|l|}{$\mathrm{V} \times \mathrm{G}$} \\
\hline F test & $\mathrm{ns}$ & $\mathrm{ns}$ & $\mathrm{ns}$ & $\mathrm{ns}$ & $* *$ & ns \\
\hline
\end{tabular}

Note: $* *=$ significantly different at $1 \%$ level; $*=$ significantly different at $5 \%$ level; ns = not significant; 
TABLE II

Matrix Correlation Variables Photosynthesis of Some Cultivars of Maize at Different Growth Stages

\begin{tabular}{|c|c|c|c|c|c|}
\hline & Chlorophyll a & $\begin{array}{c}\text { Chlorophyll } \\
\text { b }\end{array}$ & $\begin{array}{c}\text { Chlorophyll } \\
\text { Total }\end{array}$ & $\begin{array}{c}\text { The density of } \\
\text { stomata }\end{array}$ & $\begin{array}{c}\text { Stomatal aperture } \\
\text { width }\end{array}$ \\
\hline \multicolumn{6}{|l|}{ V4 stage } \\
\hline Chlorophyll a $\left(\mathrm{mg} \mathrm{g}^{-1}\right)$ & - & & & & \\
\hline Chlorophyll b $\left(\mathrm{mg} \mathrm{g}^{-1}\right)$ & $0.895 * *$ & - & & & \\
\hline Chlorophyll Total $\left(\mathrm{mg} \mathrm{g}^{-1}\right)$ & $0.973 * *$ & $0.973 * *$ & - & & \\
\hline The density of stomata $\left(\mu \mathrm{m}^{-2}\right)$ & -0.112 & -0.149 & -0.134 & - & \\
\hline Stomatal aperture width $(\mu \mathrm{m})$ & $0.333 * *$ & $0.450 * *$ & $0.402 * *$ & 0.001 & - \\
\hline Photosynthetic rate $\left(\mu \mathrm{mol} \mathrm{CO} \mathrm{Cm}_{2}^{-2} \mathrm{~s}^{-1}\right)$ & $0.406^{* *}$ & $0.395 * *$ & $0.411 * *$ & 0.052 & 0.176 \\
\hline \multicolumn{6}{|l|}{ R1 stage } \\
\hline Chlorophyll a $\left(\mathrm{mg} \mathrm{g}^{-1}\right)$ & - & & & & \\
\hline Chlorophyll b $\left(\mathrm{mg} \mathrm{g}^{-1}\right)$ & $0.802 * *$ & - & & & \\
\hline Chlorophyll Total $\left(\mathrm{mg} \mathrm{g}^{-1}\right)$ & $0.975 * *$ & $0.915 * *$ & - & & \\
\hline The density of stomata $\left(\mu \mathrm{m}^{-2}\right)$ & -0.096 & -0.024 & -0.056 & - & \\
\hline Stomatal aperture width $(\mu \mathrm{m})$ & $0.192 *$ & 0.152 & $0.187 *$ & 0.090 & - \\
\hline Photosynthetic rate $\left(\mu \mathrm{mol} \mathrm{CO} \mathrm{m}^{-2} \mathrm{~s}^{-1}\right)$ & 0.200 & $0.218^{*}$ & $0.217 *$ & 0.184 & 0.156 \\
\hline \multicolumn{6}{|l|}{ R3 stage } \\
\hline Chlorophyll a $\left(\mathrm{mg} \mathrm{g}^{-1}\right)$ & - & & & & \\
\hline Chlorophyll b $\left(\mathrm{mg} \mathrm{g}^{-1}\right)$ & $0.824 * *$ & - & & & \\
\hline Chlorophyll Total $\left(\mathrm{mg} \mathrm{g}^{-1}\right)$ & $0.974 * *$ & $0.930 * *$ & - & & \\
\hline The density of stomata $\left(\mu \mathrm{m}^{-2}\right)$ & 0.089 & 0.038 & 0.073 & - & \\
\hline Stomatal aperture width $(\mu \mathrm{m})$ & $0.222 *$ & $0.274 * *$ & $0.253 * *$ & 0.068 & - \\
\hline Photosynthetic rate $\left(\mu \mathrm{mol} \mathrm{CO} \mathrm{C}^{-2} \mathrm{~s}^{-1}\right)$ & 0.091 & -0.004 & 0.057 & 0.100 & 0.078 \\
\hline
\end{tabular}

Note: $\mathrm{N}=108$ samples; $*=$ a real contrast to the test $(\mathrm{P}<0.05) ; \mathrm{V} 4$ stage $=$ four leaved stage; $\mathrm{R} 1$ stage $=$ silk stage; $\mathrm{R} 3$ stage $=$ milk stage

\section{CONCLUSIONS}

Waterlogging that occurs at the different stage of growth affects photosynthesis by decreasing the chlorophyll content (a, b and total), photosynthetic rate and stomatal aperture width. The R1 stage is a stage of maize growth sensitive to photosynthesis when waterlogged. Bisma cultivar was the maize cultivar that was not tolerant to waterlogging stress at the V4 stage and Gumarang was not tolerant at the R3 stage. It showed a low rate of photosynthesis. At the R1 stage, Bima 5 and Bima 2 cultivars were the maize cultivars that were tolerant to waterlogging stress, while at the R3 stage all cultivars were tolerant except Gumarang was not. Therefore, Bima 5 and Bima 2 cultivars can be recommended to be planted in the swampy areas.

\section{ACKNOWLEDGMENT}

On this occasion I would like to express gratitude to the Directorate General of Higher Education, Ministry of Research, Technology and Higher Education of the Republic of Indonesia for financial support of the Domestic Postgraduate Scholarship.

\section{REFERENCES}

[1] Levitt, J. Responses of Plants to Environmental Stresses. Vol II. Water, Radiation, Salt, and Other Stresses. Academic Press. New York-London-Toronto-Sydney-San Fransisco. 1980. 607p.

[2] J. Lewis, C.F. Breeding Plants for Less Favorable Environments. A Wiley-Interscience Publication. John Wiley \& Sons. New YorkChichester-Brisbane-Toronto-Singapore. 1982. : 71-142.

[3] Yuliadi, D., .E. M.. Yanuar, J. Purwanto, and I W. Nurjaya. Socio Economical Impact Analysis and Adaptation Strategy for Coastal Flooding (Case Study on North Jakarta Region). IJASEIT. 2016. 6(3): 390-393. DOI:10.18517/ijaseit.6.3.836
[4] Thuy, Ng. Ng., and H. H. Anh. Vulnerability of Rice Production in Mekong River Delta under Impacts from Floods, Salinity and Climate Change. IJASEIT. 2015. 5(4): 272-279. DOI:10.18517/ijaseit.5.4.545

[5] Islam, M.R., A. Hamid., Q.A. Khaliq, M.M. Haque, J.U.Ahmed., and Karim, M.A. Effects of Soil Flooding on Roots, Photosynthesis and Water Relations in Mungbean (Vigna radiata (L) Wilczek). Bangladesh J. Bot. 2010. 39(2): 241-243.

[6] Li, C., D. Jiang, B. Wollenweber, Y. Li, T. Dai, dan W. Cao. Waterlogging Pretreatment During Vegetative Growth Improves Tolerance to Waterlogging After Anthesis in Wheat. Plant Science. 2011. 180: 672 - 678 .

[7] Prasarana and Rao., 2014. Effect of Waterlogging on Growth and Seed Yield in Greengram Genotypes. International Journal of Food. Agriculture and Veterinary Sciences. 2014. 4(2): $124-128$.

[8] Bloom, C.W. and Voesenek, L.A. Flooding: The Survival Strategies of Plants. Tree Physiology. 1996. 11:290-295

[9] Beckman, T.G., R.L.Perry, and J.A. Flore. Short-term Flooding Effects Gas Exchange Characteristics of Containerized Sour Cherry Trees. HortScience. 1992. 27(12):1297-1301.

[10] Henning, J., R.H.Brown, and D.A.ashley. Effect of Leaf Position and age on Photosynthesis and Translocation in Peanut I. Apparent Photosynthesis and C translocation. Peanut Science. 1979. 6: 46-50

[11] Zhao, D., K. R. Reddy, V. G. Kakani, V.R. Reddy. Nitrogen Deficiency Effects on Plant Growth, Leaf Photosynthesis, and Hyperspectral Reflectance Properties of Sorghum. Europ. J. Agronomy. 2005. 22: 391-403

[12] Suzuki, S. And H. Nakamoto, M. S. B.Ku, and G. E.edwards Influence of Leaf Age on Photosynthesis, Enzyme Activity, and Metabolite Levels in Wheat. Plant Physiol. 1987. (84): 1244-1248

[13] Fleischer, W. The Relation Between Chlorophyll Content and Rate of Photosynthesis. The Journal of General Physiology. 1934:573-597

[14] Buttery, B.R., and R.I. Buzzell. The Relationship Between Chlorophyll Content and Rate of Photosynthesis in Soybeans. Can.J. Plant Sci. 1977. 57: 1-5

[15] Lawson, T.and M.R. Blatt. Stomatal Size, Speed Stomatal Size, Speed, and Responsiveness Impact on Photosynthesis and Water Use Efficiency. Plant Physiology. 2014. 164: 1556-1570.

[16] Rahayuningsih, Sri Endang Agustina., Didik Indradewa, Endang Sulistyaningsih dan Azwar Maas. Respon Dua Varietas Jagung terhadap Durasi Genangan. Jurnal Agrienvi. 2013. 7(1): 42 - 47 [in Indonesian Language]. 
[17] Setyawan, B., I. Suliansyah, A.Anwar, and E. Swasti. Agronomic Characters, Yield Components and Grain Yield Evaluation of 11 New Hybrid Maize Prospective Genotypes. IJASEIT. 2016. 6(4): 483-488. DOI:10.18517/ijaseit.6.4.851

[18] Ezint VR, De la Pena, and A. Ahanchede. Flooding Tolerance of Tomato Genotypes During Vegetative and Reproductive Stages. EJEAFChe. 2010. 9(10): 1665- 1678.

[19] Zaidi, P.H., Y. Mamata, D.K. Singh, and R.P. Singh. Relationship Between Drought and Excess Moisture Tolerance in Tropical Maize (Zea mays L.) Australian Journal of Crop Science. 2008. 1(3):78-96.

[20] Zaidi, P.H., P. Maniselvan, A. Srivastava, P. Yadav and R.P. Singh. Genetic Analysis of Waterlogging Tolerance in Tropical Maize (Zea mays L.) Maydica. 2010. 55: 17- 26.

[21] Hossain, Md.A. and S.N. Uddin. Mechanism of Waterlogging Tolerance in Wheat: Morphological and Metabolic Adaptations under Hypoxia or Anoxia. AJCS. 2011. 5(9): 1094 -1101.

[22] Miro B, and A.M. Ismail. 2013. Tolerance of Anaerobic Conditions Caused by Flooding During Germination and Early Growth in Rice (Oryza sativa L.). Frontiers in Plant Science. 2013. 4(269): 1-18.

[23] Arnon, D.I. Copper Enzymes in Isolated Chloroplasts: Polyphenoloxidase in Beta vulgaris. Plant Physiol. 1949. 24: 1-15.

[24] Kumar, P., M. Pal, R. Joshi and R.K.Sairam. Yield growth and physiological of mung bean vegetative stage. 2013. Physiol Mol Biol plants.19(2): 209-220

[25] Kozlowski,T.T.and S.G. Pallardy. Effect of Flooding on Water, Carbohydrate, and Mineral Relations. In: Kozlowski, T.T. (ed) Flooding and Plant Growth. Academic Press, Orlando, 1984. pp 165193

[26] Celik, G. and E. Turhan Genotype Variation in Growth and Physiological Responses of Common Bean (Phaseolus vulgaris, L.) Seedling to Flooding. Afr. J. Biotechnol. 2011. 10(36): 7372-7380
[27] Kumudini, S., and T. Tollenaar, Corn Phenology. 1998 http://www.plant.uoguelph.ca/research/homepages/ttollena/research/c orn.html

[28] Anonim. Corn Plant Health Management to Help Maximize Yield Potential. 2017: 1-2 http://www.aganytime.com/Corn/Pages/Article.aspx?article=778 .17

[29] Wang X, Deng Z, Zhang W, Meng Z, Chang X, Lv M. Effect of Waterlogging Duration at Different Growth Stages on the Growth, Yield and Quality of Cotton. PLoS ONE. 2017. 12(1): e0169029. doi:10.1371/journal.pone.0169029:1-14

[30] Zaidi, P. H., S. Rafique, N.N. Singh, and G. Srinivasan. PhysioBreeding Approach for Soil Moisture Tolerance in Maize (Zea may L.). Progress and Prospects. Proceeding of the 8th Asian Regional Maize Workshop, Bangkok, Thailand: August 5-8. 2002. p 398 -412.

[31] Manzoor, T and K. Jayalalitha. Effect Waterlogging on Biochemical Parameters and Yield in Maize Hybrids. International Journal of Food, Agriculture and Veterinary Sciences. 2015. 5(2): 92 - 97.

[32] Ramadhan, R. Arieza, S. Avivi, dan Slameto. Studi Pertumbuhan Tanaman Tebu Toleran Cekaman Air Berdasarkan Karakter Fisiologisnya. Buletin Ilmiah Pertanian. 2015.1(1): 20-25[in Indonesian Language].

[33] Yudha, G.P., Z.A.Noli, M Idris. Pertumbuhan Daun Angsana (Pterocarpus indicus willd) dan Akumulasi Logam Timbal $(\mathrm{Pb})$. Jurnal Biologi Universitas Andalas. 2013. 2(2): 8 - 89. [in Indonesian Language].

[34] Wang, X., T. Liu, C. Li, and H. Chen. Effects of Soil Flooding on Photosynthesis and Growth of Zea mays L.seedlings under Differen Light Intensities. African Journal of Biotechnology. 2012. 11(30): 7676-768. [Online].Available. http://www.academicjournals.org/AJB.

[35] Yordanova, R. Y., and L. P. Popova. Flooding-induced Changes in Photosynthesis and Oxidative Status in Maize Plants. Acta Physiol Plant. 2007. (29): 535-541 